\title{
On the recipe for a varnish used by El Greco
}

\author{
Michel Favre-Félix \\ Association pour le Respect de l'Intégrité du Patrimoine Artistique (ARIPA), Montpellier, France \\ favre.felix.michel@wanadoo.fr
}

\begin{abstract}
Research into past artistic techniques has largely considered historic varnishes in a general context. However, the question of the specific varnishing practices attributable to known painters has already given rise to remarkable studies for the 19th-20th centuries, and deserves to attract greater attention for earlier artists. In this regard, the discovery of a "recipe for a varnish used by El Greco" in a 17th-century Portuguese manuscript, published in 2010, is of significant interest. The present study situates the recipe in its historic context (c. 1550-1650), discusses the nature of its ingredients as they might have been available at the time - including the "sandaraca" resin, which has a botanical origin long since subject to confusion - and proposes a set of experimental reconstructions. The results, in terms of thickness, gloss and colour, suggest new insights into $\mathrm{El}$ Greco's aesthetic choices, and calls for reflection on the modern conservation practices for the re-varnishing of his works.
\end{abstract}

\section{Sobre a receita de um verniz usado por El Greco}

\section{Resumo}

Nas pesquisas sobre as técnicas de produção artística do passado, os vernizes históricos têm sido considerados sobretudo de uma forma geral. No entanto, as práticas de envernizamento de determinados pintores dos séculos XIX e XX já originaram estudos notáveis e os artistas anteriores igualmente merecem atenção. Neste contexto tem grande interesse a "receita de um verniz usado por El Greco" descoberta num manuscrito português do século XVII publicado em 2010. O presente estudo situa essa receita no seu contexto histórico (c. 1550-1650), discute a natureza dos seus ingredientes, tal como estavam disponíveis na época - incluindo a resina "sandáraca", que há muito tem origem botânica confusa -, e propõe um conjunto de reconstruções experimentais. Os resultados, em termos de espessura, brilho e cor sugerem novas perspectivas sobre as escolhas estéticas de El Greco e suscitam reflexão sobre as actuais práticas de conservação no que respeita ao re-envernizamento das suas obras.

\section{Keywords}

El Greco

Varnish

Historical recipes

Sandarac

Restoration

Painting materials

\section{Palavras-chave}

El Greco

Verniz

Receitas históricas

Sandáraca

Conservação e Restauro

Materiais de pintura 


\section{Introduction}

The 2010 publication by Patrícia Monteiro and António João Cruz of a previously unpublished manuscript on the art of painting, dating from the first half of the seventeenth century, was a rare event [1]. The Breve Tratado de Iluminação Composto por um Religioso da Ordem de Cristo, which was found inside a book at the University of Coimbra library, numbers among the few treatises written in the Iberian Peninsula in the sixteenth and seventeenth centuries that outline artistic techniques in any particular detail [2-4]. Rarer still was the fact that this "short treatise on illumination" contains the "recipe for a varnish used by Dominico Grego", or El Greco ( $c$. 1541-1614). This discovery, which sheds new light on a previously overlooked aspect of El Greco's technique, is of great importance for the understanding of the Toledo master's aesthetic choices - and therefore also of how his paintings may once have looked.

The Tratado is written in Portuguese, with several passages in Castilian, and is a composite text in four different hands (by convention, those anonymous authors are referred to as $\mathrm{C} 0$ to $\mathrm{C} 3$ ). By carrying out an indepth historical analysis, Cruz and Monteiro were able to reconstruct the chronological order in which these interventions were made. This allowed them to pinpoint the drafting of the whole document to between 1618 and 1640 (1650 at the latest), while their investigation was devoted to the colour preparation processes mentioned in the manuscript [5]. Here, we present the first test of its varnish recipes. We will begin with a general outline, before situating the El Greco recipe in the context of historical sources from between 1550 and 1650. We will then discuss the nature of the recipe's ingredients and, finally, suggest an initial approach for its reconstruction.

\section{The origins of the varnish recipes}

The first - and primary - author (C0) outlines various illumination processes before dealing with oil techniques, but it is the author $\mathrm{C} 1$ to whom we owe the six varnish recipes (ff. 21-22). (Figure 1). The El Greco varnish, the first of the six, differs from those that follow in both length and practical guidance. Before examining it in detail, we will first consider the five other recipes.

A comparative study shows that these are, in fact, a faithful copy of the five recipes included by the painter Giovanni Battista Armenini in his book De Veri Precetti della Pittura, published in Ravenna in 1587 [6, pp. 128-130]. The ingredients, quantities and methods of preparation are identical to those of Armenini, while the phrasing is frequently similar. The Tratado simply pares down the artist's literary style to provide only the basic elements of each recipe.

Since no Spanish or Portuguese version of the Armenini's text - that we know of - was available at the time, it can be concluded that the translation and adaption were done by author $\mathrm{C} 1$ himself. His only real innovation was to invent a title for each recipe; this then raises a number of questions regarding his knowledge of the varnishes. For example, it is unclear why he has used the title of "siccative varnish" ("verniz secante") for the recipe for Strasbourg turpentine dissolved in petroleum, when the Italian text says nothing of the sort. Armenini describes this as the final varnish used by Correggio, Parmigianino and throughout Lombardy. It was not, therefore, a picture varnish designed to be added to certain colours to speed up the drying process, especially when creating a glaze. On its own, the varnish does not possess any particular siccative quality: our experiments show that it dries slowly, remaining somewhat tacky after 24 hours have elapsed.

Later on, the titles of two varnishes indicate that they are "for works painted a tempera" ("para envernizar cousas de tempara"). This specificity is intriguing because these two varnishes are lean, consisting only of resins - one sandarac and colophony, the other benzoin resin - dissolved in alcohol. Such lean mixtures are much in contrast with the traditional fat varnish used by painters in egg tempera: the famous vernice liquida of sandarac dissolved in linseed oil. These are the only completely lean varnishes, containing no oils or oleoresins, in Armenini's list; such varnishes are rarely seen in sixteenth and seventeenth century treatises, as will be discussed below. It is important to bear in mind, however, that the term tempera was not only used as a synonym for egg tempera paintings but was sometimes also employed in a broader sense [7, pp. 100-101].

In the case of the first of these two varnishes, the use of the phrase "for temperas" may well have been derived from a passage in the Italian text where Armenini notes that this varnish "è bona ancora su le tele à secco" [6, p. 129]. This is not easy to interpret, however. First of all, it is necessary to determine what Armenini means by the strange expression "on dry-painted canvases". This refers the reader back to his previous chapter, which covers methods of painting a secco on walls, panel and canvas. Elsewhere, Armenini mentions this a secco category as one of the three methods of painting, alongside the fresco and oil techniques [6, pp. 105, 110]; here, he categorises as a secco those techniques that use glue, gum arabic or tragacanth binders or various liquids, as well as, notably, the egg tempera binder. This category therefore encompasses all the methods used until the "most perfect way of oil" ("perfetissima strada del'oglio") was adopted by all the best modern artists of the age. The only works "su le tele à secco" that an Italian painter of quality could still occasionally be persuaded to undertake at the time of his treatise, Armenini adds, were decorative pieces for special occasions (such as festivals, theatrical scenery, triumphal arches etc.). These would be painted quickly and without much preparation in order to please the painter's lord and patron. Armenini concludes that such works are the responsibility of minor craftsmen and thus fall outside the scope of his book on the art of painting 


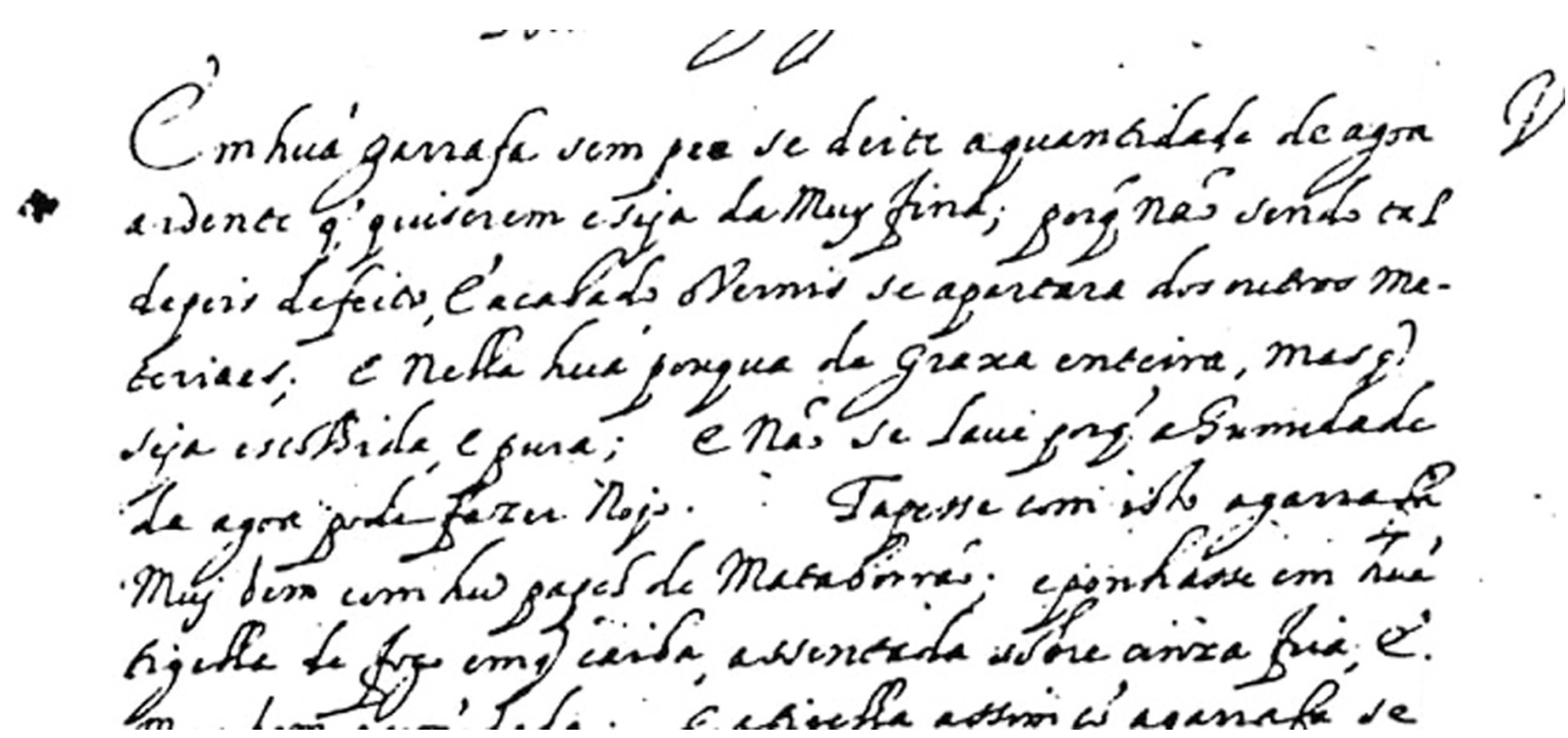

Figure 1. The beginning of El Greco's recipe (calligraphy C1), folio 21 in the Breve Tratado de Iluminação, Biblioteca Geral da Universidade de Coimbra, Códice n. ${ }^{\circ} 344$ (from [5]).

[6, p. 121]. The use of the word tempera shows that the translator avoided simply transliterating Armenini's $a$ secco, instead seeking to understand what was meant by the phrase. It seems that tempera has been used in a broader sense, in order to highlight the contrast with the oil technique.

As for the second recipe in the Tratado - given that there is nothing in the Italian text to suggest any specific use - the title of "for tempera" must be solely the work of the translator. Upon what knowledge was he able to draw? This varnish, consisting of bezoin resin dissolved in alcohol, features in several manuscripts that outline its uses. The Marciana manuscript (c. 1503-1527) mentions it three times as being used for paintings on panel, card or iron, and for illuminations [8]. In the era of the Tratado, it is referred to by Turquet de Mayerne as "varnish over gold [...] applied on figures where there is ground gold" [9], and by Pierre Le Brun as being "for varnishing gold and all other works" [10]. It was used to varnish silver and, coloured with saffron yellow, could even be used on gold. Cruz and Monteiro have noted that author $\mathrm{C} 1$ had some level of experience in gilding [5]: perhaps he recognised here a varnish used on gold or silver grounds in tempera paintings.

It is also possible that his knowledge was of a more theoretical bent. Of course, he would not have been able to consult the manuscripts mentioned above, as none of these were published until the modern era. However, this recipe and its various uses - on gold, silver, leather and other objects - did also feature in the famed book Secreti del Reverendo Donno Alessio Piemontese by Girolamo Ruscelli [11]. The Castilian translation of this work, by Alonzo de Santa Cruz, was published for the first time in 1563 [12]; this Spanish edition was used as a source of information for other colour preparation recipes reproduced in the Tratado [5].
Reading through, it is striking that the word sandaraca, which features in the third and fifth of Armenini's recipes, is oddly not translated using the equivalent Portuguese term graxa. Instead, "escandaraça" is given, a term unknown in any other Spanish or Portuguese treatise [13].

Graxa (Spanish grassa) is considered to have a dialectal origin in Morocco, whereas the Italian sandaraca derives from classical Arabic. The spelling escandaraça strongly suggests that the sense of Armenini's sandaraca was not understood and that the word was roughly transcribed. Indeed, escandaraça appears only in the recipes originally in Italian, whereas, in the same folio, $\mathrm{C} 1$ uses the regular graxa when writing the El Greco recipe. This suggests that this last recipe must have been taken directly from either Portuguese or Castilian, in which the very similar word grassa is used and is easy to understand.

Ultimately, author $\mathrm{C} 1$ does not demonstrate any great familiarity with resins and varnishes. It appears that he may well have added this chapter on varnishes to the original Tratado simply to act as a record of the El Greco recipe; we may reasonably suppose this recipe to have come from a source close to the artist, given that the Tradato was composed in the decades following $\mathrm{El}$ Greco's death. As he had no personal recipes to add to it, he then added the five Armenini recipes for good measure.

\section{El Greco's recipe: a "mixed" varnish}

In the following translation, we have introduced several clarifications to the recipe in square brackets [1, pp. 257-258]:

In a glass flask without feet add the desired quantity of alcohol [this solvent will be discussed below], which must be of the finest 
[high proof], otherwise [undissolved] materials will separate out from the varnish at the end. Add in a little whole sandarac [this resin will be discussed below], choosing the best and the most pure. Do not wash it [beforehand] as the dampness of the water is harmful to this resin.

Next, stop up the neck of the flask firmly with blotting paper [to restrict the evaporation of the alcohol]. Place this in a suitably sized pot, and put this on cooling ashes [probably preheating]. Next, put the pot containing the flask to heat over an intense fire on a small stove until the resin melts and mixes with the boiling alcohol. Then remove the flask from the heat, taking care that the cold does not break it [through thermal shock]. Open it carefully and add some Strasbourg turpentine, carefully selected [this oleoresin will be discussed below], which will mix easily with the still boiling alcohol. The amount of turpentine is up to you. Put everything back onto the heat and bring to the boil to complete. Be careful when taking the flask off the heat, as stated above. Leave the varnish to cool down and keep it for your own use.

It can be used with a paintbrush because it is liquid like water [as opposed to thick, oily varnishes]. And you can use it in two layers for a shinier result. In winter, expose [the varnished painting] to the sun [to dry it] and in summer, only to the sun's reflection, as much as the work can stand. And when the first layer is dry, add a second layer, or more. The paintbrushes can be put to soak in alcohol so that they do not set solid. This varnish is excellent for all sorts of tasks, and particularly for paper.

This must, therefore, definitely be a final varnish, intended to be added in several layers across the whole surface of the painting. This formulation is specially adapted for works on canvas, which was the most common support in use at this time in Italy. It marries a resin which adds transparency to the varnish, and ensures efficient drying - with an oleoresin (here, Strasbourg turpentine). The latter acts as a plasticiser, providing a suppleness that responds to the flexibility of the canvas. When dissolved in alcohol and used on its own on a pliant support, sandarac simply forms a dry and very brittle film over which a fine craquelure will spread.

It may be helpful here to consider such varnishes as semi-fat or mixed varnishes: due to the proportion of fat supplied in an oleoresin, they occupy the middle ground between the fat oil varnishes that were still used into the seventeenth century, and the strictly lean varnishes (resins alone, with no oil or oleoresin) that became widespread later on, particularly in the case of the more flexible mastic resin. In this respect, a simplified description of historic varnishes that separates them into only two categories ancient oil varnishes, which were then replaced by lean spirit varnishes - does not take into account the evolution whereby these mixed varnishes appeared in Italian sources from the second half of the sixteenth century $[11$, p. 246 ; 14] and became more and more prevalent in the following century. These varied in the type and combination of resins, oleoresins and solvents used.

The Marciana manuscript [8], composed between $c$. 1500-1525, records varnishes that are still all oil-based, apart from the benzoin resin in alcohol (the uses of which were discussed above) and a second recipe corresponding to Correggio's varnish, as previously mentioned.

Raffaelo Borghini's Riposo [14], published in 1584, gives an account of the four typical varnishes used on paintings at the time: Correggio's recipe, one fat and one lean varnish, and the following formulation: "Take one ounce of fine spirit, four ounces of Venetian turpentine, and half an ounce of crushed mastic, and mix all of these materials together well in a glass jar, and then place it in the sun for three days, stirring the mixture a few times, and this will give you an excellent varnish".

The Paduan manuscript [15] is considered to be a collection of recipes spanning the period from the end of the sixteenth century to the following century [9, pp. $65-66 ; 16]$. It includes some lean formulas (three recipes) but already nearly as many mixed varnishes (five) as fat varnishes (six).

It is possible that in the case of the fat varnishes, the manuscript was being used as a repository for old recipes in the process of being phased out. However, it is important to note that oil varnishes were still very common at the beginning of the seventeenth century, both in Italy (Caravaggio, for example [17]), and even more so in northern Europe. Théodore Turquet de Mayerne provides a first-hand account of Rubens' arguments against resin / oleoresin varnishes - which, as they dried, were vulnerable to the dampness of the northern climate - and of his attachment to fat varnishes (f. 7v). De Mayerne seems to share Rubens' convictions, as in the margins of several recipes for nonoily varnishes he suggests adding "a little nut or linseed oil blanched in the sun [as] this prevents them from melting and makes them resistant to water and air" (f. 110r).

De Mayerne collected his recipes between 1620 and 1646. Considering those that were definitely for use by painters (discounting his experiments into formulations with amber in oil) it is notable that his manuscript features far fewer fat varnishes (three different recipes) and lean varnishes (three) than mixed varnishes (seven), in addition to those with oleoresin only (three). The El Greco recipe is therefore one of the resin/oleoresin mixtures that became standard in this era. However, it belongs to the particularly unusual and narrow category of those using alcohol - a solvent that is relatively uncommon for oil paintings - as we will see below.

The Paduan manuscript contains a similar recipe to the El Greco varnish although the preparation is slightly different [15, p. 691]: it recommends grinding the sandarac to a powder and mixing it with Strasbourg turpentine, before adding the alcohol and putting the mixture on to boil over a gentle heat until it is like water. Finally, the mixture needs to be transferred to a fresh vessel without disturbing the material deposited at the bottom of the first flask.

De Mayerne records a formulation with sandarac in alcohol (fl. 110r), although not noted to be for paintings, in which the Strasbourg turpentine - omnipresent in the Italian treatises quoted above $[6,8,15]$ - is replaced by Venice turpentine, a balsam that appears constantly in 
his manuscript. All the other mixed varnishes that he has transcribed are based on essential oils, and often mastic is given in the place of sandarac.

Later, this was also the case for the ordinary varnish used in Rembrandt's circle, according to his pupil Samuel van Hoogstraten [18, p. 223]: [Venice?] turpentine, turpentine essential oil and mastic. The El Greco formula can also be found in treatises from the eighteenth century by Bonanni [19, pp. 19, 25] or Guidotti [20, p. 90].

The text of the El Greco recipe is remarkably lively and rich in recommendations based on experience, but it does not mention the quantities of ingredients required. However, we might consider whether contemporary varnishing practices may have helped to determine certain proportions of ingredients, while at the same time allowing for some variation (i.e. "the amount of turpentine is up to you"). In order to address this question, we propose an approach based on the reconstruction of historical recipes for the same type of varnish, beginning with the quantities given in the Paduan MS. For the reconstructions to be credible, the ingredients selected must be as close as possible to those available in El Greco's lifetime. Below, we address this issue for each ingredient in turn.

\section{The ingredients}

\section{"Trementina de beta"}

The Portuguese expression "tromentina de beta" in Nunes [2, p. 73r] - equivalent to the Spanish "trementina de veta" in Pacheco [3, p. 412] and "de beta" in Palomino [21, p. 329] - theoretically refers to the balsam derived from the silver fir, Abies alba: the "oglio di abezzo" of the Italians, commonly called Strasbourg turpentine [22, p. 711;23, p. 163].

It is possible that, in some cases, the painters' descriptions may indicate subtly different substances. For example, Pacheco's "trementina de veta de Francia" could have applied to the balsam of the spruce Picea abies Karst., extracted particularly in the Vosges region and known as Jura turpentine [22, p. 711; 23, p. 165]. And it cannot be ruled out that his "trementina de beta blanca" corresponds to the variety of "oglio d'abezzo chiaro" cited by Armenini. Such a particularly clear balsam was indeed harvested in the Italian Tyrol [7, pp. 471, 481]. It has recently been reintroduced by Kremer [24] - this production, which might have previously been provided under the name of 'd'abezzo', is a less coloured type of Venice turpentine tapped from the larch.

Since the El Greco recipe is not this precise, we will use the classic Strasbourg turpentine (sourced from Kremer Pigmente, Munich).

\section{"Graxa"}

This Portuguese term, also used by Philippe Nunes $[2$, f. $72 v]$, is similar to the Spanish grassa in Pacheco [3, p. 410], grasa in the Andalusian Tractado [4, p. 126] and grasilla in Palomino [21, p. 328]: all specific HispanoPortuguese terms equivalent to the Italian sandaraca. Outside Spain and Portugal, during the medieval period this resin was known in the West as vernix, a term that appears in botanical texts until the nineteenth century. In the context of a reconstruction it is important to attempt to pin down the exact nature of this resin, as it has been interpreted in various ways over the course of the centuries.

Nowadays, sandarac is clearly identified as the resin exuded by a conifer of the cupressaceae family, Tetraclinis (earlier thuya) articulata (Vahl.) Mast., which is particularly common in the Atlas Mountains. However, this provenance did not start to become known until the end of the eighteenth century. Before this point, the tree itself, which was cultivated in remote regions, had not been correctly distinguished or described. It was finally classified in 1791 by Martin Hendriksen Vahl.

Back in the era of El Greco - who was active between c. 1570 and 1614 - sandaraca was considered in the West to be a juniper resin. This idea gained traction largely through a work of pharmacopoeia: the commentaries or discourses of Sienese physician Pietro Andrea Matthioli on the ancient Dioscorides treatise De Materia Medica [25], and the Spanish equivalent by Andrès Laguna [26]. These well-known treatises, which went through multiple, richly illustrated editions, were a possible source of information for painters. Pacheco, for example, when mentioning grassa as a juniper resin [3, p. 141] gives "Dioscorides, cap. 83" (i. e. chapter 83 of Laguna's work) as a reference.

Sandaraca-vernix continued to be associated with various types of juniper until the beginning of the nineteenth century. In 1827, the Dictionnaire des Sciences Naturelles finally put an end to the confusion:

Sandarac (Bot.). Resin extracted from a tree of the conifer family. It had long been believed that it was produced by the common juniper; but after Broussonet, cited by M. Desfontaines, in his Flora atlantica, it is produced by the thuya articulata of the latter, common in the kingdom of Morocco, whence it is imported [27].

The modern scientific literature has interpreted these data in two separate ways. According to Eastlake [7, p. 238] and Merrifield [28, p. ccliii], the ancient authors had confused the still unknown tree with the juniper. However, the sandarac resin used at the time was nevertheless a product of the Tetraclinis. This explanation is supported by researchers at the Doerner Institute, who have confirmed this later botanical provenance for, at the least, the eighteenth century varnishes under scrutiny in their study [29, pp. 379-394]. In contrast, other commentators maintained that the ancient authors had simply used the generic denomination of sandaraca to cover the historical use of various resins from different botanical junipers.

No complete study of the history of the vernixsandaraca resin has yet been published. The detailed 


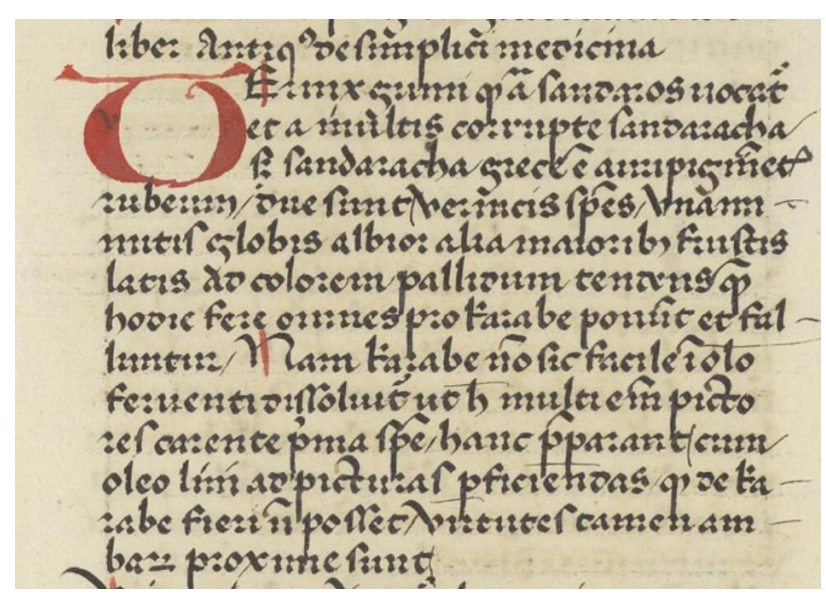

Figure 2. "Vernix gummi quod arabum sandaros vocatur \& a multis corrupte sandaracha ; sed sandaracha graece est auri pigmentum rubeum". Extract from the Clavis Sanationis, the medical lexicon compiled by Simon of Genoa in $c .1290$. Physicians frequently complained of the corruption of the Arabic sandaros into sandarac $(h) a$ : in Greek pharmacopoeia sandaracha was already the name for the mineral realgar, or red orpiment, which led to the risk of this dangerous arsenic sulphide being prescribed instead of the resin. Notably, in this medical lexicon, vernix is directly presented as the basis for the painters' oil varnish without any reference to its medical uses. Wellcome Library, London, MS 167 (fl. 95r).

survey of pharmacopoeia (materia medica) texts that we have undertaken in conjunction with the present article confirms the confusion of the ancient authors. We can present only a brief overview here.

As we have noted, the medieval texts used the term vernix (or bernix, bernice or bernize) for the resin, which, when dissolved in oil, made up the ubiquitous vernice liquida. In the mid- twelfth century, a list of synonyms drawn up by the great translator Gerard of Cremona reveal that vernix was none other than the Arabic sandaros resin [30]. The term, transposed as sandarax, was then deformed to $\operatorname{sandarac}(h) a$ [31] (Figure 2). It was already known by this time that the resin came "from trees grown beyond the seas" [32] (Figure 3), but it was not linked to the juniper, which was only noted for the use of its berries, smoke fumigations and wood oil. The resin was therefore imported, and not of European origin.

In fact, all of the therapeutic indications for vernixsandaraca mentioned by European physicians came to them from Arab pharmacopoeia, either translated into Latin or transmitted through the Schola Medica Salernitana. Although some Arabic authors described the resin with consistency and precision, none of them mentioned which local tree was its source. Neither did they refer to its use as a varnish, although its use by painters was constantly cited by Western physicians [32]. This later insistence is remarkable because these physicians say nothing of the kind for mastic, nor for other resins also used in varnishes.

In reality, sixteenth century Western authors were ignorant of the botanic provenance of this resin. Modern commentators have limited themselves to citing Matthioli's work in its first editions $(1544,1548)$, and often assume him to be well informed. However, the later, revised and expanded editions need to be studied in order to understand that the physician did not know the source tree for the resin. In his scholarly Latin edition of 1565 [25, p. 122], Matthioli went back on his previous statements to agree with others that the sandarac could be the resin of the oxycedar (Juniperus oxycedrus L., or prickly juniper) instead of the (common) juniper:

There are those who think that the Sandaracha of the Arabs is not the gum of the juniper, but of the "oxycedar", called the sharp cedar. I willingly concede to such an opinion, as there are very few among them who do not believe that the prickly juniper is none other than the large juniper, to the extent that many would not be able to distinguish between the two [33].

This shows that the question was a matter of opinion rather than knowledge, which at the time was still often based on ambiguous, archaic descriptions and on the reliability of remote sources.

Because this attribution to the juniper came neither from direct knowledge, nor from the Arab treatises translated into Latin, it must have been transmitted informally through the medium of local terminology.

As a matter of fact, the same term ar'ar (راعرع) was used throughout the Arab world for the common juniper, the Phoenician juniper and the prickly juniper (Figure 4) [34], as well as for the Tetraclinis articulata itself - the Tetraclinis not being a juniperus but bearing some resemblance to this genus [35-36]. Arar tree has, incidentally, become the modern international Englishlanguage term for the latter tree. It is accordingly feasible that, in the course of direct exchanges between North African suppliers and European traders, this resin would have been described as having come from an ar'ar. Since

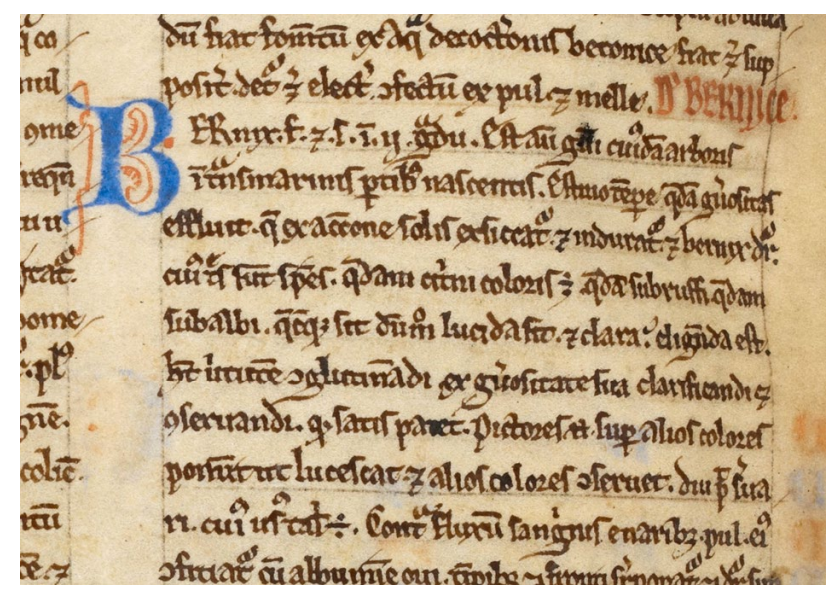

Figure 3. "Bernix [...] Est autem gummi cuiusdam arboris in ultra marinis partibus nascentis' - and on its use by painters for a varnish, both giving brightness and preserving their colours - "quoniam pictores super alios colores ponunt ipsam ut melius luceant: \& alios colores conservet". Extract from the Liber de Simplici Medicina or Circa Instans, composed by Matthaeus Platearius in Salerno between 1130 and 1160. British Library, London, Harley MS 270 (fl. 128v), transcription with reference to its first edition in Venice, 1497. 


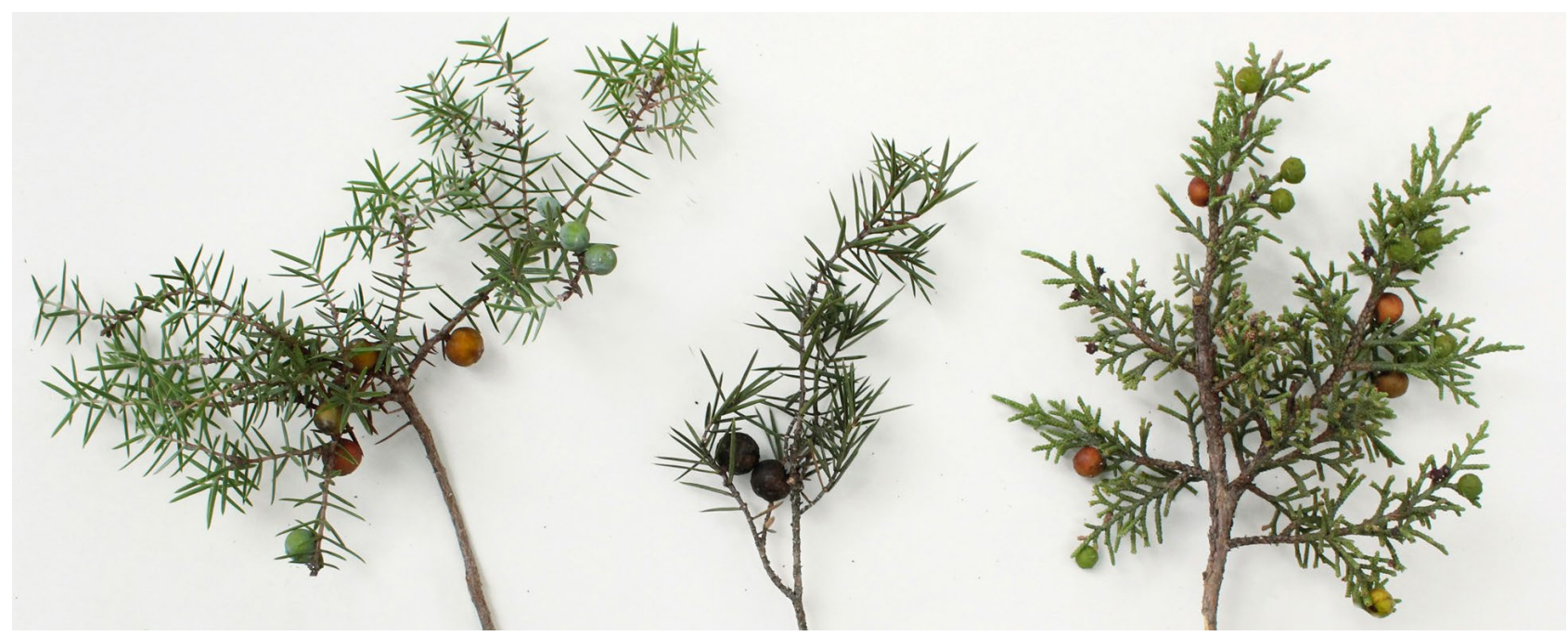

Figure 4. From left to right: Juniperus oxycedrus L., J. communis L., and J. phoenicea L. Collected by the author in August and September in the Languedoc region (southern France).

in Arabic botany, ar'ar designated mainly several sorts of junipers, it would have spread under the simplified, ambiguous form of resin from the juniper.

The "large juniper" mentioned above by Matthioli is, effectively, a theoretical tree mentioned by Dioscorides [37] and Pliny [38]. These ancient authors, who were obligatory references during the Renaissance, distinguished in essence between two types of juniper, the small and the large. However, they did not provide sufficient detail to allow these to be correlated with precise species. The small is generally identified with the common juniper and/or with the oxyceder, but the identity of the "large juniper" (sometimes called "juniperus arbor") remains a matter for conjecture. As a result, the oxycedar and an indeterminate "large juniper" were the two trees constantly cited as sources for the varnish in European treatises that would copy one another for two centuries to come.

In the sixteenth century, therefore, materia medica texts demonstrated an obvious ignorance of the origin of this imported substance. This makes it unlikely that a particular Juniperus in Europe would have been systematically exploited for its resin in this period. In the seventeenth century, meanwhile, these texts did not improve in accuracy as much as might have been expected. The information they provided was still vague and unclear: as well as the prickly juniper, the resin of which was said to be very rarely found, they mentioned an ill-defined African large juniper with no documented description (Figure 5):

That which comes from the Oxycedar is considered the best, but it is very rare. We are only brought that of the large Junipers, which grow to a great height $\&$ are very numerous in Africa [39].

Could a tree other than the Tetraclinis have supplied a resin in North Africa, imported under the name of sandaraca? Our investigations show that the only supported hypothesis is that of a potential Middle Eastern harvest from the Juniperus oxycedrus L., classified by the Arabs as ar'ar but by the ancients as kédros. However, although there is extensive documentation of the extraction of oil from this shrub - also known as the cade - from the Middle Ages, and even antiquity [38, XVI 52 ], to the modern day, clues that its resin has ever been used for a varnish remain to be established. Although it could possibly be Pliny's cedria resin, it is not clear where or when its harvest could have taken place, nor how the practice could have fallen into obscurity on the eve of the nineteenth century and been lost to history.

It might have been hoped that the modern techniques of gas chromatography and mass spectrometry could be used to analyse samples of ancient varnish and so dispel the confusion. Paradoxically, however, they have helped to perpetuate it. The results thus obtained have identified the family of origin as the Cupressaceae, but without being able to narrow this to genus or species (Tetraclinis, various types of juniper, cypress etc.). This limitation has inadvertently served to support the idea that several of these different trees, particularly various species of Juniperus, were in the past used to supply the resins for varnishes under the generic name of sandaraca. However, this idea, which is frequently repeated in conservation circles, is based on the imprecision of these analyses and has no scientific credibility of its own. It is not supported by any study of the resins cited and does not explain where or when such trees are supposed to have been exploited.

More recently, through the use of a new analysis procedure, Steigenberger has been able to distinguish characteristic markers for the Tetraclinis: the resin is characterised by the exclusive presence of hydroxy- and acetoxy-sandaracopimaric acids, which are present in high amounts [23]. This method has been used to prove that a sample of historic sandaraca, received in England in 1701 by the chemist John Francis Vigani, was indeed a Tetraclinis articulata resin - even though at this date, 

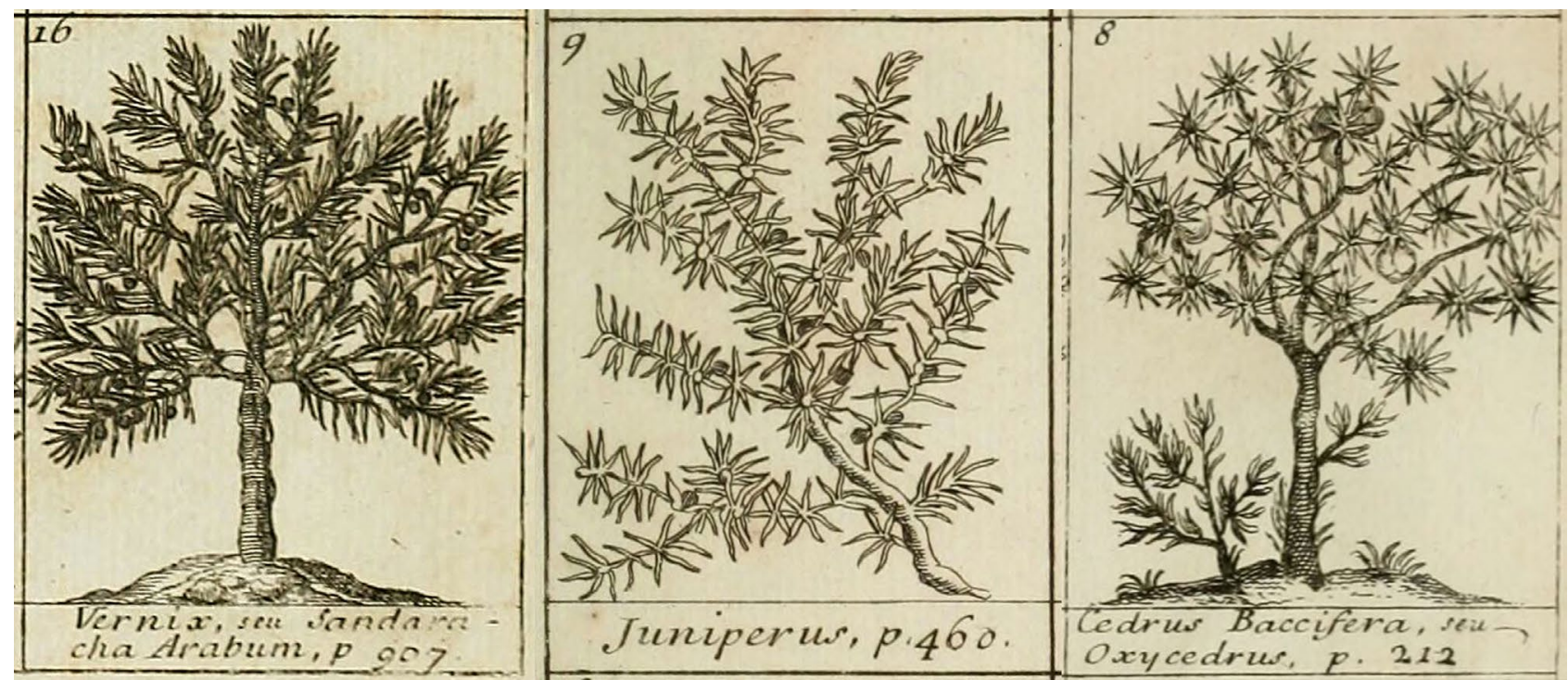

Figure 5. Prints selected from Lemery's Dictionnaire Universel des Drogues Simples (1733 edition) [38]. The source of vernix is illustrated by the image of a rather indeterminate large African tree, the trunk of which exudes tears. This is notably different from the common juniper and from the oxycedar.

as throughout the sixteenth and seventeenth centuries, it would have been unanimously attributed to the juniper.

Alongside the critical textual study that has established the history of such confusion, these are to date the only scientific data that have shed light on the issue. We will therefore adopt them as a point of reference, and will regard the grassa-sandaraca that may have been used by El Greco as corresponding to the sandarac extracted from the Tetraclinis (sourced from Laverdure or Sennelier, Paris, of North African origin).

\section{"Agoa ardente"}

Aqua ardens (burning water) was the medieval term used for distilled wine and was maintained in Spanish and Portuguese. Aqua vitae appeared in a medical context at the beginning of the fourteenth century and the expression prevailed in Italian and French [40-41]. Such brandies, containing $40 \%$ or $50 \%$ alcohol, were already widely produced in the fourteenth century [22, p. 32]. Additional cycles of distillation - sometime using salt of tartar produced stronger spirits containing 60-80 \% alcohol. According to Perego, this was the highest alcohol strength commonly available in 1800 [22, p. 32].

There are several points to be made about the solvent in this recipe. As far as the old recipes provide details, it rarely appears in varnishes designed to be used on oil paintings. Alcohol varnishes are favoured for other surfaces such as metal, wood, paper, paintings in non-oil media, etc. [42, pp. 229-232]. This is possibly due to the penetrative and dissolving properties of alcohol on oil, particularly when still fresh. Watin warns that spirit of wine varnishes cause the chapping of colours and are therefore unfit for paintings [42, p. 240]. Notably, the few alcohol varnishes that are explicitly designed for paintings (and not just objects) nearly always contain an oleoresin, undoubtedly as much in an attempt to alleviate this risk as for its plasticising properties. Two rare exceptions to this rule are found in Pacheco and Palomino [21, p. 328]. As a matter of fact, Pacheco makes frequent references to agua ardiente, even suggesting it for the dissolution of mastic when nothing like as strong a solvent is needed [3, p. 411]. When considering this domination by alcohol, it is tempting to suggest that it may in fact have been particular to the Spanish school.

Here, in any case, alcohol is required to dissolve the sandarac. Oil aside, this was not the only traditional solvent that could have been used effectively. Spike lavender essential oil, which is not mentioned by most modern commentators, completes the task after fifteen minutes in a water-bath: much more easily and completely than the alcohols available at the time. However, it was apparently less widely available and more expensive, as well as sometimes being fraudulently contaminated. An attempt to dissolve the sandarac can be used as a test: as noted by de Mayerne, if it dissolves badly, this means that the spike lavender oil is not pure but has been adulterated with ordinary turpentine (f. 53r). Watin notes that sandarac "cannot tolerate weaker spirits, [but dissolves] over a naked flame or in strong spirits" [42, p. 209], as our experiments have confirmed.

The term agoa ardente in our recipe therefore refers to spirits redistilled several times to extract the maximum amount of water, once known as the phlegmatic part: this explains the expression sflematt[issi]ma in the Paduan manuscript. These successive distillations were also called cooking, as in Armenini ("acqua di vita di tre cotte") or Pacheco ("agua ardiente de siete cosiduras").

We started from a $90 \%$ medicinal alcohol containing no additives (from the Laboratoire Cooper pharmaceutical company). For our first two tests, one part was diluted to approximately $60 \%$ by the addition of distilled water (based on the measurements in the Gay-Lussac alcohol 
a
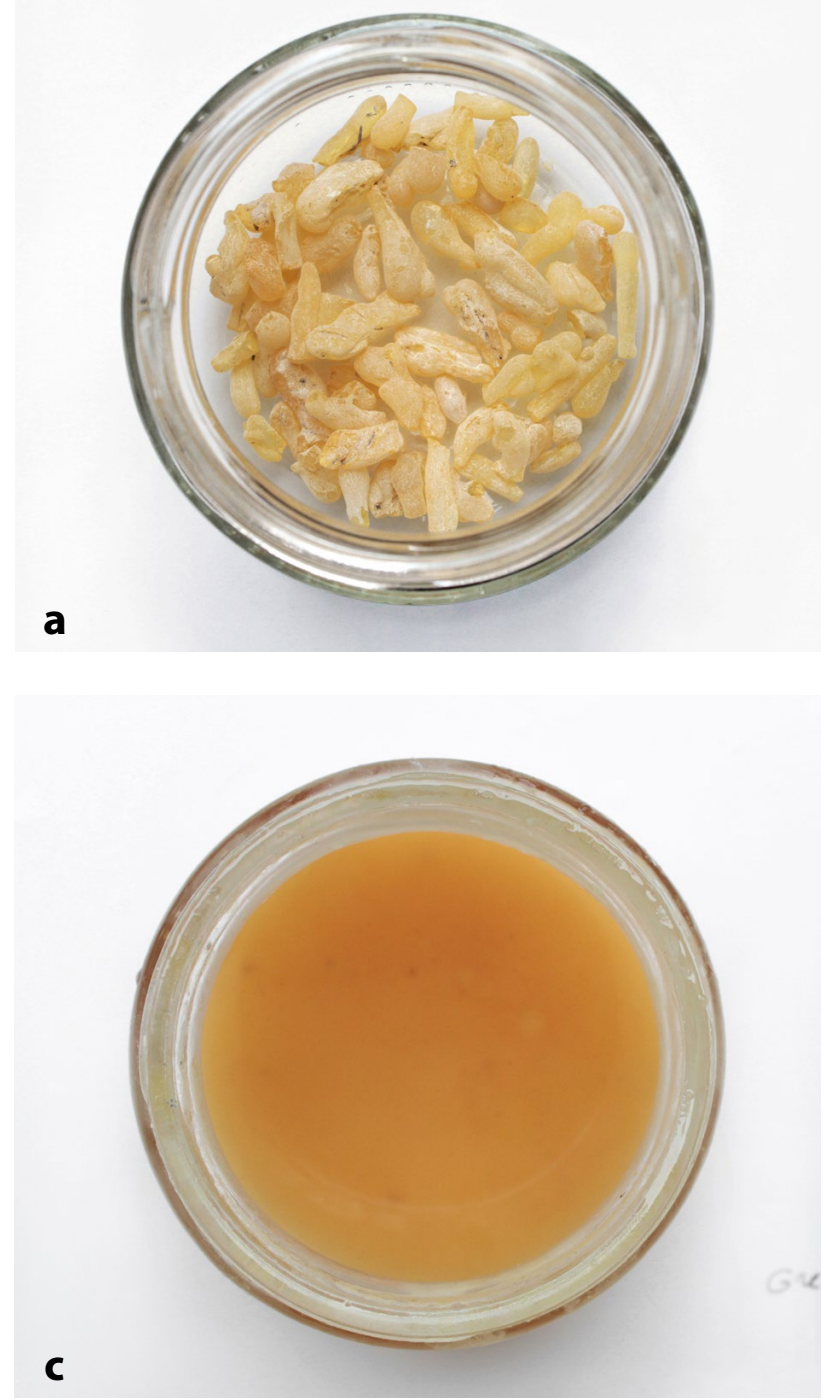

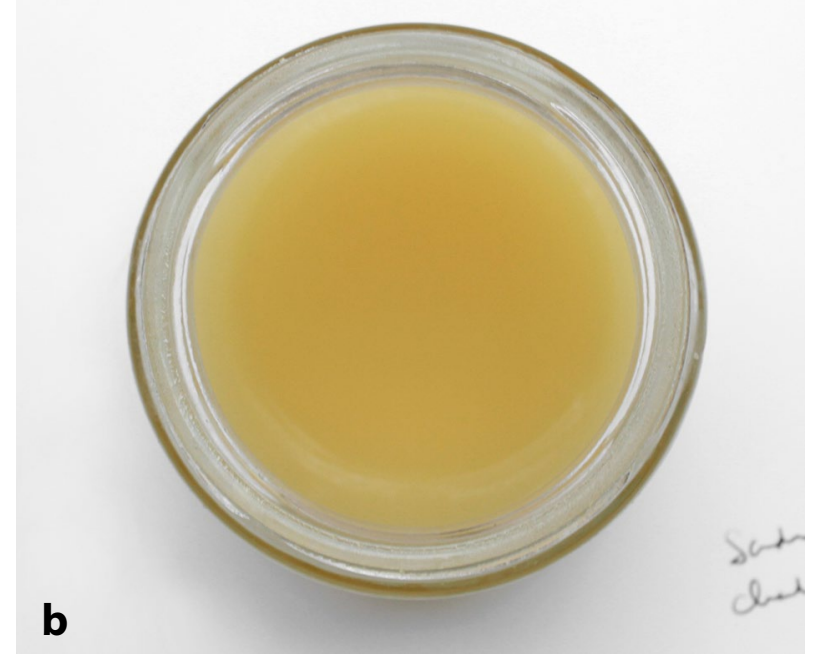

d

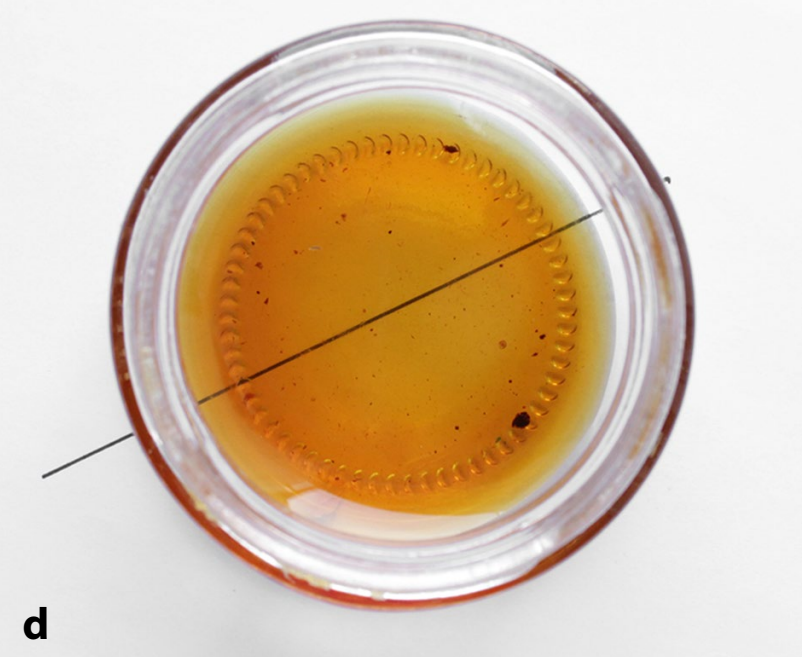

Figure 6. a) sandarac tears; $b$ ) sandarac dissolved in alcoholic spirit at $\approx 75 \%$; ) the same, with Strasburg turpentine added; $d$ ) the transparency of the varnish left in the vessel and fully dried.

dilution table). The other part was diluted to approximately $75 \%$ for the tests that followed.

\section{First reconstruction tests}

These initial experiments were based on the quantities given in the Paduan manuscript: "oz.7. acquevita sflematt[issi]ma, oz. due Sandaraca, oz. due abiezzo" [15, p. 691]. Interestingly, the two recipes both highlight the use of their varnish for paper, while other equivalent recipes (which are addressed below) do not do so: the recipe from the Paduan MS is entitled "per pitture e carte alla Fiaminga", while the El Greco recipe ends with "para todas as cousas principalmente para papel".

For both controllability and safety, we chose to heat the samples using a water bath. The glass vessel was sealed with a screw top.

First test: the sandarac ( $8 \mathrm{~g})$, crushed into a powder, was mixed with $\approx 60 \%$ alcohol $(30 \mathrm{~g})$, before the vessel was placed in the water bath. Fairly quickly, most of the resin became stuck together in a glutinous, whitishyellow mass. This could be drawn out into strands but was impossible to liquefy. The alcohol floated and was barely coloured.

Second test: Since the Tratado recipe demanded "graxa enteira", the test was repeated using whole sandarac tears. The dissolution was much improved, but took place much more slowly and gradually. After an hour, only partial dissolution was achieved, leaving an amount of residue stuck to the bottom of the vessel.

Third test: The sealed vessel, containing the whole sandarac $(8 \mathrm{~g})$ and our alcoholic spirit at $\approx 75 \%$ (30 $\mathrm{g})$, was placed in the water bath. It was briefly agitated approximately every five minutes. The dissolution was even, although less and less rapid; it was complete after three quarters of an hour, but the mixture was somewhat cloudy (Figure 6b). When we checked, it transpired that this was due to a minor, light component of the sandarac 
that had dispersed rather than dissolved. When the Strasbourg turpentine ( $8 \mathrm{~g}$ ), previously warmed to liquefy it, was added, it finally melted into the oleoresin.

The resulting varnish was a light, milky orangeyyellow liquid emulsion (Figure 6c). However, despite this turbidity, the varnish, once brushed onto a surface and allowed to dry, readily becomes completely transparent (Figure 6d).

\section{Remarks}

Several of the recipe's instructions were confirmed by our tests. First of all, the sandarac dissolved better when used whole rather than as a powder. Most of the comparable recipes cited above [3, p. 411; 14, p. 221; 15 , p. 691], required the resin to be reduced to a powder, a method that proved to be fitting for spirits at $\approx 75 \%$ but appears to promote incomplete dissolution for spirits at $\approx 60 \%$. As a result, the Paduan MS calls for the varnish to be transferred in order to separate it from the undissolved material in the bottom of the flask, which was not necessary here. The El Greco recipe therefore seems remarkable in having been based on practical experience and testing.

Secondly, the recipe correctly recommends using an alcohol with the highest percentage by volume, so that the substances do not stick together in an undissolved mass. This observation suggests that 75-80\% alcohols were sufficiently available by the end of the sixteenth century. Such spirits are mentioned by de Mayerne as "burning all [completely]": the traditional test consisted of setting light to the spirits in order to identify those that contain the least amount of water and therefore burn entirely.

According to the Paduan MS, from which we borrowed the quantities, the making of this recipe leads to a waterlike varnish - "falla bollire dolcemente al foco sino che tutto diventi acqua". Yet, in practice, the Strasburg

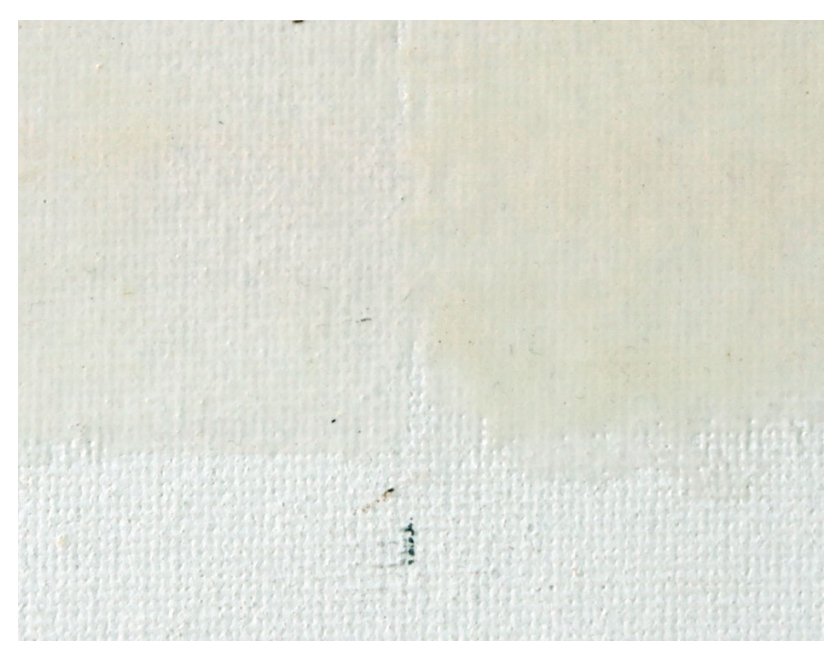

Figure 7. The effect of the reference varnish - colour and coating of the structure of the canvas - in one layer (left) and in two layers (right). turpentine is only partially miscible with alcohol [22, p. $714]$ and the "spirit of wine" also contains $\approx 25 \%$ water; their mixture is a milky colloidal suspension, as shown by our result, which is liquid but less so than pure water. As a result, the comparison could not be taken in a narrow literal sense, but should be interpreted in its historical context.

Interestingly, the same analogy is used in the Tratado"o uso delle he pondoo com o pincel, porque fiqua liquido como agoa". Above all, the text emphasises the fluidity of El Greco's varnish for allowing its application with "brush or paintbrush". The simile with water makes sense in contrast with traditional oil-based preparations, some of which were so viscous that they needed to be rolled out with the fingers or the palm of the hand.

Heating promotes the homogeneity of the mixture (as for other mixed varnishes) so evidently that it is logical in practice to apply the varnish when it is still lukewarm. It might have been familiar enough not to be noted in every text. Warming, even of the painting itself, features in the Paduan MS but not in the Tratado. Similarly, it is recommended by Guidotti but not by Bonanni.

Whether lukewarm or cooled, this varnish has to be applied confidently as it sets rather quickly, which is not ideal for touch-ups. The resulting varnish was not yet dry to the touch after an hour, but had dried sufficiently after two. Because of its relative viscosity and quick setting, it was not possible to apply a very thin layer as a film. Although fluid, the varnish had enough body to coat the relief of the brushstrokes and the texture of the canvas, and had a shiny finish. Its light yellow tone was visible when the first layer was applied, and became obvious with the second (Figure 7).

\section{Further reconstructions}

In order to assess the results of this initial approach, we extended our investigation as completely as possible to treatises on painting and on varnishing, as well as books of secrets and technical writings, from French, Italian and Spanish sources, spanning a long period from 1557 [11] to 1773 [42]. The search focused on the specific type of varnish attributed to El Greco: based on spirit of wine, composed of oleoresins and resins, and explicitly intended for oil paintings. Eventually, in addition to the recipe from the Paduan MS, we found six different recipes which met these three criteria (see their ingredients and proportions in Table 1).

These reconstructed varnishes proved to be remarkably similar to our first test in terms of gloss, coating and natural colour. The appearance of Borghini's spirit varnish is identical to our reference result (Paduan MS proportions of ingredients), even though it uses mastic and Venice turpentine (for which we chose a clear variety from Talens). The two varnishes noted by Bonanni in 1720 were no different from our first reference, while the varnish recorded by Guidotti in 1764, which uses a 
Table 1

Formulations of different "mixed" varnishes based on alcohol, as found in the literature

\begin{tabular}{|c|c|c|c|c|c|c|c|}
\hline \multirow[b]{2}{*}{ Source } & \multirow[b]{2}{*}{ Recipe } & \multirow[b]{2}{*}{ Date } & \multirow[b]{2}{*}{ Alcohol (g) } & \multicolumn{2}{|c|}{ Oleoresin } & \multicolumn{2}{|l|}{ Resin } \\
\hline & & & & Type & $\begin{array}{l}\text { Weight } \\
\text { (g) }\end{array}$ & Type & $\begin{array}{l}\text { Weight } \\
\text { (g) }\end{array}$ \\
\hline Paduan MS & {$[15$, p. 691$]$} & 16th-17th century & 30 & ST & 8 & $\mathrm{~S}$ & 8 \\
\hline Borghini & {$[14$, p. 221$]$} & 1584 & 6 & VT & 24 & M & 3 \\
\hline Pacheco & {$[3$, p. 411] } & 1649 & 28 & ST & 8 & B & 14 \\
\hline Auda & {$[40$, p. 296] } & 1668 & 28 & ST & 3.5 & $\mathrm{~S}$ & 7 \\
\hline Bonnani & {$[19$, p. 19] } & 1721 & 28 & ST & 10.5 & S & 7 \\
\hline Bonnani & {$[19$, p. 24$]$} & 1721 & 30 & ST & 6 & $S$ & 6 \\
\hline Guidotti & {$[20$, p. 90$]$} & 1764 & 30 & ST & 5 & $\mathrm{~S}$ & 7.5 \\
\hline
\end{tabular}

Oleoresin: $\mathrm{ST}=$ Strasburg turpentine, $\mathrm{VT}=$ Venice turpentine. Resin: $\mathrm{B}=$ benzoin, $\mathrm{M}=$ mastic, $\mathrm{S}=$ sandarac.

Note: The weights correspond to our own reconstructed samples when following the proportion of ingredients noted in the historical recipes. When a formulation is repeated in several treatises over the studied period, the date and author of its first publication are indicated.

smaller proportion of oleoresin, was only barely less coloured.

Pacheco's recipe obviously merits attention. He was some twenty years younger than El Greco, whom he met in 1611. His book, published after his death, likely reflects practices from his period of activity (c. 1590-1638), which significantly overlapped that of the master of Toledo. In his recipe, benzoin takes the place of sandarac and we chose the clear Tyrol turpentine (discussed above) to represent his "trementina de veta blanca" (both from Kremer).

The result was equally as coating and coloured than our reference test, with a hue closer to a greyish-ochre tone.

The varnish that features in Domenico Auda's compendium of secrets [43, p. 296] is the only lighter

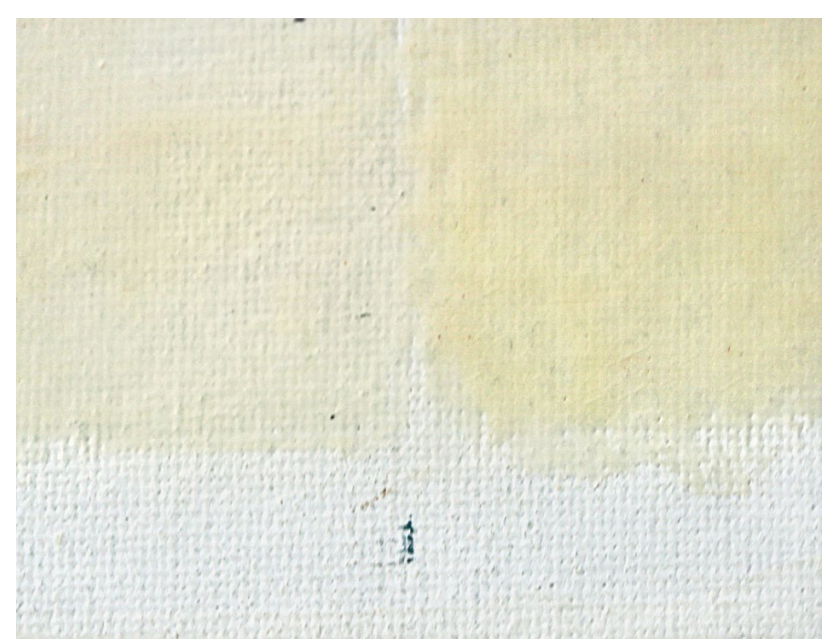

Figure 8. The appearance of the same sample after nine months' storage in indirect daylight. varnish: two layers of this are visually equivalent to a single layer of the others. While he advises elsewhere the use of another regular essential oil varnish for paintings [43, p. 143], the author states that this one is "known only to a few" and can restore old paintings "as if they were new". This use evokes a method of over-varnishing in which a fresh light varnish brushed over the old varnish restores the transparency that it had lost over time, thereby improving the painting's legibility (at least for a period of time). Alcohol is especially efficient for this process, and this could explain its higher proportion in this formulation.

In order to make these comparisons, we had to make afresh our reference varnish based on the quantities given in the Paduan MS. Our initial sample was no longer suitable, for the simple reason that about nine months had elapsed since its making and photographic documentation (Figure 7), and, although our sample had been stored in the studio in indirect daylight, we realised that it had undergone a surprising and marked yellowing over this short period (Figure 8).

\section{Conclusion}

We observed a high level of aesthetic similarity between the reconstructed varnishes - particularly from Borghini, the Paduan MS and Pacheco, which are closer in time to El Greco. It can therefore be assumed that his paintings most certainly featured a varnish of this kind, which smoothed out the texture of the brushstrokes, had a lustrous shine and was slightly amber-yellow in tone. The rapid yellowing of its ingredients deserves to be considered in greater depth.

These characteristics are vital for our understanding not only of how paintings were made, but also "and more 
importantly, of how they appeared", as Mark Leonard has written on the subject of original varnishes [44].

As a result of these findings, it seems relevant to question the varnishing criteria prevailing in modern conservation practice. These promote the use of nonyellowing, colourless resins and advocate the thinnest layer of varnish in order to coat the relief of the paint as little as possible, supposing this choice to be faithful to the intentions of the artist; they also most frequently privilege a semi-matte finish.

As Leslie Carlyle - whose reconstructions of traditional mastic varnishes show that painters must have routinely acknowledged their very rapid yellowing - has stated, this fact "not only is important in terms of how paintings appeared in the past, it is significant in terms of what is used as replacement varnish today" [45].

\section{Translation from French by Alison Clarke}

\section{Acknowledgements}

I am grateful to Prof. António João Cruz for his encouragement, as well as for his advice in translating the recipe from the 17th century Portuguese. I wish to thank Alison Clarke for her patience and talent, along with Paul Taylor (Warburg Institute) for his reading, criticism and suggestions.

\section{References}

1 Monteiro, P. ; Cruz, A. J., 'Breve Tratado de Iluminação composto por um religioso da ordem de Cristo', in The Materials of the Image. As Matérias da Imagem, ed. L. U. Afonso, Cátedra de Estudos Sefarditas «Alberto Benveniste» da Universidade de Lisboa, Lisboa (2010) 237-286, https:// www.academia.edu/7268175/.

2 Nunes, P., Arte da Pintura, Symmetria, e Perspectiva, Lisboa (1615), http://acervo.bndigital.bn.br/sophia/index. asp?codigo_sophia=39177 (accessed 2017-05-08).

3 Pacheco, F., Arte de la Pintura su Antiguedad y Grandezas, Sevilla (1649), https://archive.org/details/HArteR03T09.

4 'A tract on the art of painting, ca. 1656', in Artists' Techniques in Golden Age Spain. Six treatises in translation, ed. Z. Veliz, Cambridge University Press, Cambridge (1986) 109-127.

5 Cruz, A. J.; Monteiro, P., 'Sobre um tratado inédito de pintura da primeira metade do século XVII: o Breve Tratado de Iluminação, composto por um religioso da Ordem de Cristo', in The Materials of the Image. As Matérias da Imagem, ed. L. U. Afonso, Cátedra de Estudos Sefarditas «Alberto Benveniste» da Universidade de Lisboa, Lisboa (2010) 147-169, https://www.academia.edu/7268206/.

6 Armenini, G. B., De Veri Precetti della Pittura, Ravenna (1587), https://books.google.com/books?id=RxtXAAAAMAAJ.

7 Eastlake, C. L., Methods and Materials of Painting, Dover, New York (2001).

8 'Divers secrets', in Medieval and Renaissance Treatises on the Arts of Painting, ed. M. P. Merrifield, Dover Publications, New York (1999) 608-640.

9 De Mayerne, T. Turquet, 'Pictoria, sculptoria et quae subalternarum artium, 1620', in Berger, E., Quellen für
Maltechnik Während der Renaissance und Deren Folgezeit (XVI.-XVIII. Jahrhundert), München (1901) 98-364, https:// archive.org/details/bub_gb_UHprAAAAMAAJ.

10 Le Brun, P., Recueuil des essaies des merveilles de la peinture, in Medieval and Renaissance Treatises on the Arts of Painting, ed. M. P. Merrifield, Dover Publications, New York (1999) 765-841.

11 Ruscelli, G., Secreti di Don Alessio Piemontese Nuovamente Stampati, Lucca (1557), https://books.google.com/books?id=BXZVAAAAcAAJ.

12 Ruscelli, G., Secretos de Don Alexo Piamontes [...] Traduzidos de Lengua Latina en Castellana, por el Licenciado Alonson de Sancta Cruz, Anvers (1564), https:// books.google.com/books?id=EDY6AAAAcAAJ.

13 Cruz, A. J., personal communication (2016).

14 Borghini, R., Il Riposo, Firenze (1584), https://archive.org/ details/riposodiraffaello0borg.

15 'Recipes for all kinds of colours', in Medieval and Renaissance Treatises on the Arts of Painting, ed. M. P. Merrifield, Dover Publications, New York (1999) 648717.

16 Canevari, C.; Zanchi, S., 'Filippo Bonanni, Athanasius Kircher et les connaissances sur la gomme lacque entre le XVIIe et le XVIIIe siècle', in De la Peinture à l'Instrument de Musique: Vernis, Liants et Couleurs, ed. S. Vaiedelich \& J.-P. Echard, Musée de la Musique, Paris (2008) 26-32.

17 Arciprete, B. 'Il restauro', in La Flagellazione di Caravaggio. Il Restauro, ed. D. M. Pagano, Electa, Napoli (2004) 39-40.

18 Hoogstraten, van S., Inleyding tot de Hooge Schoole der Schilderkonst, Rotterdam (1678), https://archive.org/details/ inleydingtotdeho00hoog.

19 Bonanni, F., Trattato Sopra la Vernice Detta Communemente Cinèse, $2^{\text {nd }}$ ed., Rome (1731), https://archive.org/details/trattatosopralav00buon.

20 Guidotti, A. M. A., Nuovo Trattato di Qualsivoglia Sorte di Vernici Comunemente Dette della China, Bologna (1764), https://archive.org/details/bub_gb_3Q-mruBcyuUC.

21 Palomino de Castro y Velasco, A., El Museo Pictorico y Escala Optica, vol. 2, Madrid (1797), https://archive.org/ details/elmuseopictorico23palo.

22 Perego, F., Dictionnaire des Matériaux du Peintre, Belin, Paris (2005).

23 Steigenberger, G., 'The Vigani Cabinet - Analysis of historical resinous materials by gas chromatography - mass spectrometry and infrared spectroscopy', dissertation doctor rerum naturalium, Technical University Dresden, Dresden (2013), http://nbn-resolving.de/urn:nbn:de:bsz:14-qucosa-117317.

24 'Lärchenterpentin aus Südtirol, nicht raffiniert', in Kremer Pigmente, http://www.kremer-pigmente.com/de/laerchenterpentin-aus-suedtirol-nicht-raffiniert-62002.html?number=62002 (accessed 2017-03-16).

25 Matthioli, P. A., Petri Andrea Matthioli Senensis Medici, Commentarii in Sex Libros Pedacii Dioscoridis Anazarbei De medica materia, Venice (1565), https://archive.org/details/PetriAndreaMatt00Matt.

26 Laguna, A., Pedacio Dioscorides Anazarbeo, Acerca de la Materia Medicinal, Anvers (1555), https://books.google. com/books?id=hG0rnSNIDykC.

27 Dictionnaire des Sciences Naturelles, vol. 47, StrasbourgParis (1827), https://archive.org/details/darwinonline_1816-30_Dictionnaire_A767.47.

28 Merrifield, M. P. (ed.), Medieval and Renaissance Treatises on the Arts of Painting, Dover Publications, New York (1999). 
29 Koller, J.; Baumer, U.; Schmid, E.; Grosser, D. 'SandarakSandarac' in Lacke des Barock Und Rokoko. Baroque and Rococo Lacquers, ed. K. Walch, J. Koller \& M. Baumeister, Bayerisches Landesamt fur Denkmalpflege, Munich (1997) 379-394.

30 Cremona, G., 'Breviarium medicinae', manuscript, British Library, London, Harley MS 1914, folio 130v (c. 11141187).

31 Genoa, S., Synonima medicinae, Milano (1473).

32 Platearius, M., 'Liber de simplici medicina or Circa instans', manuscript, British Library, London, MS 270, folio $128 \mathrm{v}$ (1130-1160).

33 Matthiole, P. A, Les Commentaires de M. Pierre André Matthiole [...] sur les Six Livres de Ped. Dioscoride Anazarbeen de la Matiere Medecinale, Lyon (1572), https:// books.google.pt/books?id=bMZCAAAAcAAJ.

34 Lemery, N., Dictionnaire Universel des Drogues Simples, Paris (1733), https://archive.org/details/ dictionnaireuniv00lm.

35 Duke, J. A., Handbook of Medicinal Plants of the Bible, CRC Press, London-New York (2007) 226-228.

36 A Guide to Medicinal Plants in North Africa, IUCN Centre for Mediterranean Cooperation, Malagà (2005), https://portals.iucn.org/library/node/8882 (accessed 2016-10-25).

37 Dioscorides, Pedanii Dioscoridis Anazarbei De Materia Medica Quinque, 2 vol., Leipzig (1829-1830), https:// archive.org/details/b23982500_0001 and https://archive.org/ details/b23982500_0002.

38 Pline l'Ancien, Histoire Naturelle, Paris (1830).

39 Lemery, N., Traité Universel des Drogues Simples, Paris (1698), https://archive.org/details/traituniverselde00lmer.

40 Chastrette, M., 'Histoire de la distillation des essences et de l'alcool', communication, 55èmes Journées Nationales du congrès de l'UdPPC, Paris (2007), http://paris2007.udppc. asso.fr/docactes/2007/132_05032008102240.doc (accessed 2017-05-08).

41 Rasmussen, S. C., The Quest for Aqua Vitae: The History and Chemistry of Alcohol from Antiquity to the Middle Ages, Springer, Cham (2014), https://doi.org/10.1007/978-3-31906302-7.

42 Watin, J. F., L'Art du Peintre, Doreur et Vernisseur, $2^{\text {nd }}$ ed., Paris (1773), http://gallica.bnf.fr/ark:/12148/bpt6k841821.

43 Auda, D., Breve Compendio di Maravigliosi Secreti [...] con Nuova Aggionta dell'Istesso Auttore, Venice (1668), https:// books.google.pt/books?id=JY48AAAAcAAJ.

44 Leonard, M.; Khandekar, N.; Carr, D.W., 'Amber varnish and Orazio Gentileschi's Lot and his Daugthers', The Burlington Magazine 143(1174) (2001) 4-10, http://www. jstor.org/stable/889066.

45 Carlyle, L., 'Representing authentic surfaces for oil paintings: experiments with 18th- and 19th-century varnish recipes', in Art of the Past - Sources and Reconstructions, ed. M. Clarke, J. H. Townsend \& A. Stijnman, Archetype Publications, London (2005) 82-90.

Received: 2016-11-02

Revised: 2017-03-23

Accepted: 2017-04-18

Online: 2017-06-09

This work is licensed under the Creative Commons Attribution-NonCommercial-NoDerivatives 4.0 International License.

To view a copy of this license, visit http://creativecommons.org/licenses/by-nc-nd/4.0/deed.en. 